\title{
Symbiotic reproductive strategies of Austinixa aidae in the southwestern Atlantic Ocean, Brazil: sexual maturity of females, fecundity and egg features
}

\author{
Douglas Fernando Peirón ${ }^{1,2}$, Emerson C. Mossolin ${ }^{3}$, Fernando L. Mantelatto ${ }^{1, *}$ \\ ${ }^{1}$ Laboratory of Bioecology and Crustacean Systematics (LBSC), Postgraduate Program in Comparative Biology, \\ Department of Biology, Faculty of Philosophy, Science and Letters at Ribeirão Preto (FFCLRP), University of São Paulo, \\ Av. Bandeirantes 3900, 14040-901, Ribeirão Preto, São Paulo, Brazil \\ ${ }^{2}$ Laboratory of Aquatic Biology, Department of Biological Sciences and Health (DCBS), University of Araraquara (Uniara), \\ Rua Carlos Gomes 1338, CEP 14801-340, Araraquara, São Paulo, Brazil \\ ${ }^{3}$ Department of Biological Sciences of Federal University of Goiás (UFG), Regional Catalão, \\ Av. Lamartine Pinto de Avelar 1120, CEP 75704-020, Catalão, Goiás, Brazil
}

\begin{abstract}
A great variety of reproductive strategies have been observed among brachyurans. Most strategies aim to maximize offspring survival, maintain population stocks, and differentially increase parental genes. We hypothesized that reproductive strategies of a symbiont are not similar to other related but non-symbiotic brachyuran crabs. To test this hypothesis, we analyzed the following parameters of the pea crab Austinixa aidae, symbiont to ghost shrimp Callichirus species, from the southeastern coast of Brazil: fecundity and its seasonal variation, egg size and volume, number of developing eggs, and the relationship between fecundity and crab size and weight. Reproductive parameters of $A$. aidae were strongly related to the mean size of individuals. Females reached sexual maturity at $5.1 \mathrm{~mm}$ carapace width, corroborating previous allometric research. A positive correlation between number of eggs with body size and weight was found. The reproductive period of this species was classified as seasonally continuous. Many early stage eggs were found in all reproductive periods, indicating high reproductive potential. Additionally, the proportion of early stage eggs found during the period of the study indicates a rapid embryonic development. The effects of latitude, environmental conditions, and host mesohabitat characteristics in combination influence reproduction in symbiotic species.
\end{abstract}

KEY WORDS: Brachyura · Callianassidae · Callichirus · Fitness · Pinnotherid · Pinnotheridae • Reproduction · Sandy beach

\section{INTRODUCTION}

The Brachyura is a highly diverse group of crustaceans distributed worldwide that have a great variety of reproductive strategies to maximize offspring survival and population stock maintenance (Hartnoll \& Gould 1988), and differentially increase parental genes (R. Bauer pers. comm.). Growth, molt cycles, gonadal development, reproductive patterns, morphologic maturity, and fecundity are some of the

\footnotetext{
*Corresponding author: flmantel@usp.br
}

main aspects of the reproductive biology studied in these crustaceans (Pinheiro \& Terceiro 2000).

Fecundity (number of eggs per clutch) is used to determine the reproductive potential of a species and/or the input into the population. Study of fecundity enables inferences to be made about the adaptations and reproductive strategies of a species with respect to environmental conditions and the possible influences of habitat, intra/inter-specific resources, and lifestyle (see Sastry 1983 for review).

(C) The authors 2014. Open Access under Creative Commons by Attribution Licence. Use, distribution and reproduction are unrestricted. Authors and original publication must be credited. 
It is also possible to analyze differences between non-symbiotic species and symbiotic species regarding reproductive strategies. The reproduction of nonsymbiotic crabs, like that of most crustaceans, is directly related to factors such as temperature, salinity, and food availability, and these 3 factors can also be related to latitude. For symbiotic crabs, there are factors in addition to the ones mentioned above that are of extreme importance, such as the size of the host, its burrow (if it is a burrowing species), and their behavior within this burrow. For example, McDermott (2005) examined pinnixid crabs living with Amphitrite and Chaetopterus (tubicolous polychaetes) and found differences between individuals of the same species in different hosts and latitudes, mainly concerning size, breeding season, brood size and the number of broods per season, and Ocampo et al. (2012) found a close relationship between female crab and host bivalve body size for Calyptraeotheres garthi.

Egg size is another important life cycle parameter that affects reproductive performance, and sometimes it is the only way to quantitatively determine the contribution of a generation to progeny (Timofeev \& Sklyar 2001). Egg volume is considered an indicator of energy input to embryonic development, since the quantity of yolk decreases as the embryo grows and develops. Thus, estimating egg volume is important in order to understand population mechanisms used to face the environmental challenges affecting survival and reproduction (Hernáez \& Palma 2003).

The period and level of reproduction may be estimated from the occurrence and proportion of ovigerous females and/or females with complete gonadal development throughout the year (Pinheiro \& Terceiro 2000, Turra \& Leite 2000). Determination of these ecological features and other factors controlling reproduction allows a better understanding of the life history and reproductive strategies of a species (Sastry 1983).

Pinnotherid crabs are typically small and form symbiotic associations with a wide variety of benthonic invertebrate hosts (Schmitt et al. 1973, Williams 1984, Harrison \& Hanley 2005). Austinixa species are symbionts of ghost shrimps (axiidean crustaceans or ecologically equivalent species) and are found on sandy beaches (Heard \& Manning 1997, Harrison 2004, Peiró \& Mantelatto 2011). The body characteristics of Austinixa (much wider than long and with the third pair of walking legs more developed than the other pairs) are an adaptation to their symbiotic lifestyle inside the narrow axiidean burrows (Heard \& Manning 1997). A. aidae, the target species, has a western Atlantic geographic distribution, from the state of
Amapá to the state of Rio Grande do Sul in Brazil (Peiró \& Mantelatto 2011).

Few studies were found in the literature which addressed the reproductive strategies of the genus Austinixa. Some reproductive parameters have been referred to in publications primarily focused on population dynamics, biology, or mating systems of $A$. patagoniensis (Rathbun, 1918) (Alves \& Pezzuto 1998), A. gorei (Manning \& Felder, 1989) (McDermott 2006) and A. aidae (Righi, 1967) (Peiró \& Mantelatto 2011, Peiró et al. 2011, 2013). Additionally, studies of reproduction within pinnotherid symbiotic relationships are scarce, e.g. Dissodactylus mellitae (Rathbun, 1900) (Bell \& Stancyk 1983) and Calyptraeotheres garthi (Fenucci, 1975) (Ocampo et al. 2012). Other relevant studies concerning reproduction of pinnotherids are: Hines (1992), who investigated general patterns of reproductive output, and Lardies \& Castilla (2001), who examined the effects of latitudinal variation on the reproductive biology of Pinnaxodes chilensis.

Because there is little information regarding this topic for pinnotherids, we chose to investigate the reproductive strategies of the symbiont $A$. aidae, a burrow-living pea crab in relationship with intertidal ghost shrimps of the genus Callichirus. We hypothesized that the strategies of $A$. aidae are not similar to other related but non-symbiotic brachyuran crabs. To test this hypothesis, we analyzed fecundity and its seasonal variation, egg size and volume, number of developing eggs, the relationship between fecundity and crab size and weight, and the relationship among reproductive parameters and environmental factors in a population from the northern coast of the State of São Paulo.

\section{MATERIALS AND METHODS}

Pea crabs Austinixa aidae were collected from the galleries of their host, a ghost shrimp species of the genus Callichirus. Samples were obtained during the day, at low tide, and in the intertidal zone (in a plot $\sim 400 \mathrm{~m}$ long by $\sim 30 \mathrm{~m}$ wide). Samples were collected bimonthly from May 2005 through September 2006 at Perequê-açu Beach, Ubatuba, State of São Paulo, Brazil (232 $\left.24^{\prime} 59^{\prime \prime} \mathrm{S}, 45^{\circ} 03^{\prime} 17^{\prime \prime} \mathrm{W}\right)$. The study site is a semi-protected, dissipative sandy beach. Both crustaceans were collected using commercial suction pumps (100 cm long and $5 \mathrm{~cm}$ in diameter) developed by Rodrigues (1966) and were similar to those described by Manning (1975). The surface water temperature and salinity were measured before sampling. 
Pea crab individuals were separated from sand using a $1 \mathrm{~mm}$ mesh sieve, placed in individual plastic bags, labeled, frozen, and transported to the laboratory for analysis. We are confident that our sampling procedures avoided the loss of eggs. All materials were preserved in ethanol $(80 \%)$ until further examination. In the laboratory, crabs were sexed by their pleopods. Male crabs have 1 pair of long and thin pleopods (gonopods) on the ventral surface of the first abdominal somite and 1 pair of short pleopods on the second abdominal somite. Female crabs have 4 pairs of long setose pleopods from the second to the fifth abdominal somites. Specimens with undifferentiated pleopods or undeveloped pleopods were considered juveniles (Peiró et al. 2011, 2013). The carapace width (CW) and abdominal width (AW) (between the fourth and fifth abdominal somites) were measured under a stereomicroscope with a drawing tube $(0.1 \mathrm{~mm}$ precision). The wet weight (WW) was measured with an electronic analytical scale (0.0001 $\mathrm{g}$ precision) to assess its possible correlation with the number of eggs. Individuals were drained using paper towels before taking measurements. Among decapods, fecundity is generally related to the size or weight of ovigerous females (Ogawa \& Rocha 1976, Mantelatto et al. 2002, Peiró et al. 2013). The crabs were deposited in the Crustacean Collection of the Department of Biology, Faculty of Philosophy, Science and Letters at Ribeirão Preto, University of São Paulo (CCDB/FFCLRP/USP) under the catalogue no. 2102.

A previously studied dataset of females (Peiró \& Mantelatto 2011, Peiró et al. 2011) were utilized here, in order to compare different approaches used to determine their maturity. Females were classified into the following 3 groups using the size of the smallest ovigerous female as a reference (see Peiró et al. 2011): (1) Immature, females <5.1 mm CW; (2) Mature non-ovigerous, females $\geq 5.1 \mathrm{~mm} \mathrm{CW}$ without eggs adhered to pleopods; (3) Ovigerous, females $\geq 5.1 \mathrm{~mm} \mathrm{CW}$ with eggs adhered to pleopods. Ovigerous females were also classified according to the following stages of egg development, based on Boolootian et al. (1959) and modified by Mantelatto \& Garcia (1999): Early (Stages 1 to 4), yolk occupying all to 3/4 of the egg, eyes of larvae not visible; Intermediate (Stages 5 to 8), yolk reduced to $1 / 4$ of the egg, eyes visible; Final (Stages 9 to 10), yolk absent, zoea becomes visible. During development, egg volume increases due to embryonic growth. The thickness and resistance of the membrane prevents egg enlargement (Lardies \& Wehrtmann 1996).

Only crabs with early stage embryos were selected for the fecundity and egg volume analyses. Use of recently spawned eggs is preferable for fecundity studies because this reduces error related to egg loss throughout development due to predation, parasitism (Mantelatto \& Fransozo 1997), and unidentified sources of embryo mortality (e.g. displacement of increasingly larger embryos within a small space; mechanical displacement when the female is moving about in a narrow space) (Corey \& Reid 1991, Bauer 2004).

The eggs were carefully removed from the pleopods and counted under a stereomicroscope. Females with intermediate and final stage eggs were used to estimate egg loss and differences in egg volume during embryonic development.

The average volume $\left(\mathrm{mm}^{3}\right)$ of each egg was calculated using Jones \& Simons' (1983) formula $1 / 6 \pi I^{3}$ (where $I$ is the mean of the minimum and maximum diameters of these ellipsoid eggs) with a subsample of 15 eggs per female. This calculation was applied to eggs at all developmental stages to evaluate changes in volume during the incubation period (ANOVA). The minimum and maximum diameters of each egg were measured under a stereomicroscope with a drawing tube $(0.1 \mathrm{~mm}$ precision).

The normality of the size distribution of ovigerous females was assessed with the Kolmogorov-Smirnov (K-S) test. The number of size classes was determined according to Sturges (1926) as follows: $k=1+$ $\log _{2} n$, where $k$ is the number of classes and $n$ is the size of the sample.

The Pearson product moment correlation was used to determine the relationship of the CW and the WW of ovigerous females with the number of eggs. The same coefficient was used to investigate the correlation between environmental factors (water temperature and salinity) and ovigerous females. The mean fecundity per size class was also determined. To better visualize seasonal fecundity, bimonthly samples were grouped into Summer (January), Autumn (March and May), Winter (July), and Spring (September and November), according to Mantelatto \& Garcia (1999). Results were considered statistically significant when $\mathrm{p}<0.05$ (Zar 1996). Statistics and graphics were performed using the programs SPSS Statistics and Microsoft Office Excel, respectively.

\section{RESULTS}

\section{Abundance and ovigerous females}

A total of 588 crabs were collected during the study: 247 males $(42.0 \%), 265$ females $(45.1 \%)$, and 76 juve- 
niles $(12.9 \%)$. There were 55 ovigerous females (9.4\% of all individuals and $20.8 \%$ of all females). Ovigerous females occurred throughout the study, except in July 2005, and ranged from 7.1 to $50.0 \%$ of all females; the highest proportion was found between November and May (warmest months) (e.g. May [50.0\%] and November 2005 [41.2\%]; March [31.6\%] and May 2006 [29.6\%]). Immature females made up a greater proportion between March and September (Fig. 1). There was no correlation between water temperature $\left(23.9 \pm 2.3^{\circ} \mathrm{C}, \mathrm{r}=-0.125, \mathrm{p}=0.789\right)$ or salinity $(27.3 \pm 8.5 \%, r=-0.237, p=0.608)$ and the total number of ovigerous females.

The mean size of ovigerous females (CW) was $8.1 \pm$ $0.9 \mathrm{~mm}$, ranging from 5.1 to $10.5 \mathrm{~mm}$. Only 3 ovigerous females were smaller than $7 \mathrm{~mm}$, and most were between 7 and $9 \mathrm{~mm} \mathrm{CW}$ (Fig. 2). The size frequency distribution of ovigerous females was unimodal (K-S test, $\mathrm{p}=0.092$ ).

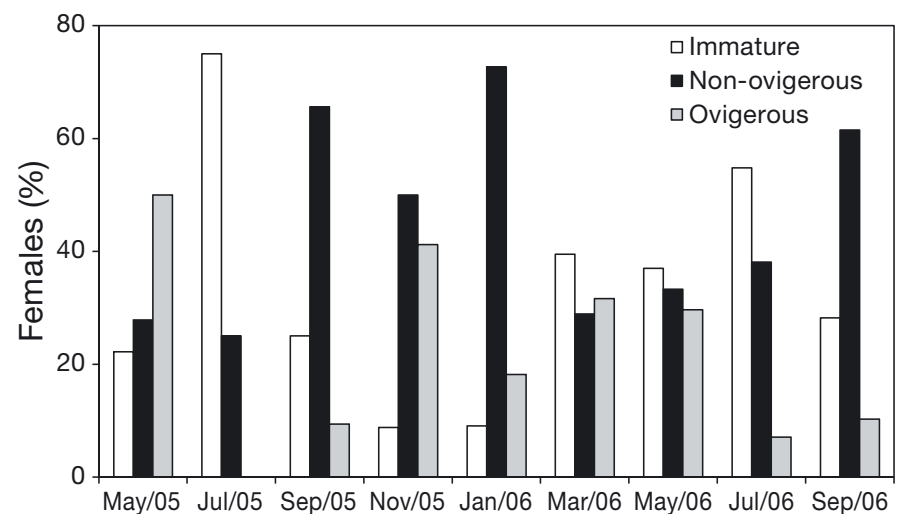

Fig. 1. Percentage of immature, non-ovigerous and ovigerous Austinixa aidae females collected in Callichirus galleries at Perequê-açu beach, Ubatuba, São Paulo, Brazil, from May 2005 to September 2006

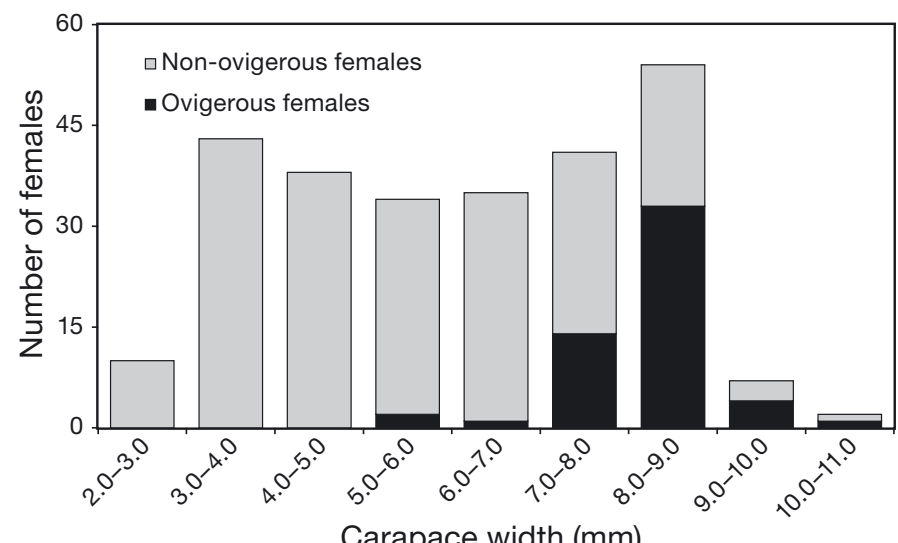

Carapace width $(\mathrm{mm})$

Fig. 2. Size-frequency distribution (carapace width) of Austinixa aidae females collected in Callichirus galleries at Perequê-açu beach, Ubatuba, São Paulo, Brazil, from May 2005 to September 2006
The relationship between the AW/CW ratios versus the $\mathrm{CW}$ in addition to the minimum size of ovigerous females $(5.1 \mathrm{~mm} \mathrm{CW})$ revealed that mature females had AW/CW ratios $\geq 0.41$ (Fig. 3), approximately corresponding to $5.1 \mathrm{~mm} \mathrm{CW}$. We observed a gap in dispersion points at $\mathrm{AW} / \mathrm{CW}$ ratios $\geq 0.41$ and $\mathrm{CW} \geq 5.1 \mathrm{~mm}$ (Fig. 3) and an inflection around $7 \mathrm{~mm} \mathrm{CW}$.

Ovigerous females carrying early stage eggs $(78.2 \%)$ were found during the entire study period, with frequencies over $40.0 \%$ (except July 2005; and $100 \%$ in September 2005 and January, July, and September 2006) (Fig. 4). Females carrying intermediate and final stage eggs comprised 14.5 and $7.3 \%$ of all females, respectively, and were found only in months with higher reproductive activity.

\section{Fecundity and egg features}

The mean fecundity of 25 ovigerous females carrying early stage eggs was $1024 \pm 441$ eggs, ranging from $204(5.1 \mathrm{~mm} \mathrm{CW})$ to 2039 eggs $(8.1 \mathrm{~mm})$. The early stage eggs were orange or whitish and rounded and had a mean diameter of $0.23 \pm 0.02 \mathrm{~mm}$ and a mean volume of $0.0061 \pm 0.0012 \mathrm{~mm}^{3}$. Mean fecundity of ovigerous females carrying intermediate stage eggs was $965 \pm 244$ eggs and that of females carrying final stage eggs was $732 \pm 369$ eggs. This is an indicator of the reduction in the number of eggs through development. The mean volume was $0.0074 \pm$ 0.0016 and $0.0078 \pm 0.0025 \mathrm{~mm}^{3}$ for the intermediate and final stages, respectively; the eggs were also rounded.

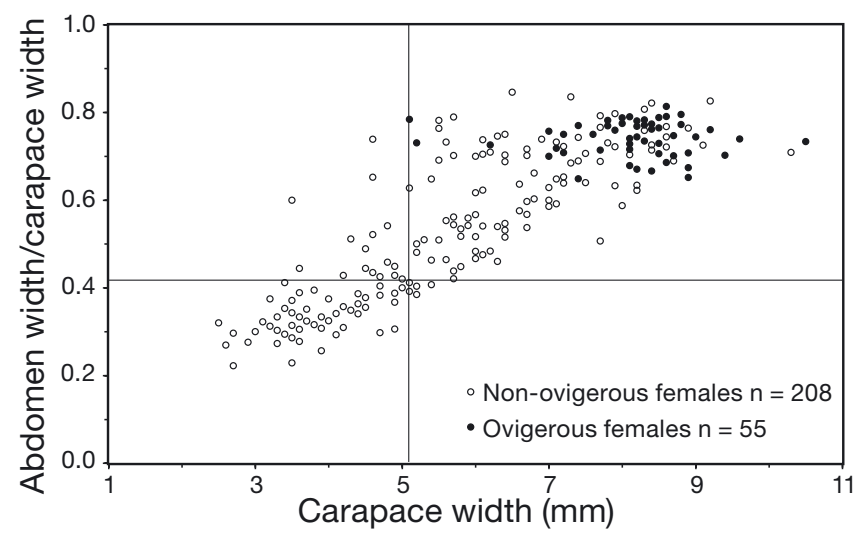

Fig. 3. Maturation of Austinixa aidae females collected in Callichirus galleries at Perequê-açu beach, Ubatuba, São Paulo, Brazil, from May 2005 to September 2006. Ratios between abdominal width and carapace width versus carapace width. The upper right quadrant represents morphologically mature females 


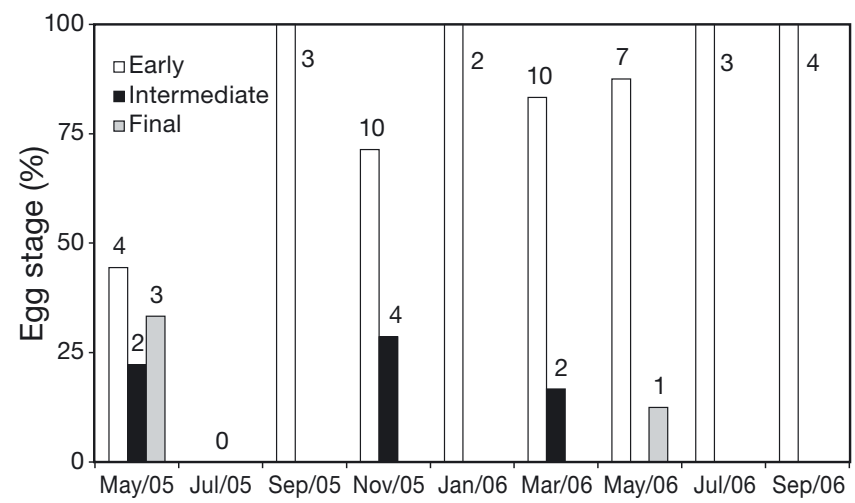

Fig. 4. Egg stage frequency of Austinixa aidae collected in Callichirus galleries at Perequê-açu beach, Ubatuba, São Paulo, Brazil, from May 2005 to September 2006. The numbers above the bars indicate the total number of individuals per stage

Egg volume tends to increase during embryogenesis; the average egg volume of all 3 developmental stages was significantly different (ANOVA, $F=17.00$, $\mathrm{p}<0.001$ ). Egg number (early stage) was correlated with the CW $(r=0.85)$ and WW of females $(r=0.80)$ $(p<0.05)$ (Fig. 5). The mean number of eggs increased with CW and also with size class (Fig. 6).

Differences in the seasonal means of the number of eggs were evident during the sampling period. The lowest means occurred in Spring 2005 and 2006 (611 \pm 370 and $782 \pm 504$ eggs, respectively). Non-ovigerous females were collected in Winter 2005 (Fig. 7). The highest mean number of eggs occurred in Autumn 2005 (1276 \pm 386 eggs). The smallest ovigerous females occurred in the low fecundity season (Spring 2005 and 2006).

\section{DISCUSSION}

Our results indicate that Austinixa aidae have some reproductive traits that might be influenced by the symbiotic relationship with the ghost shrimp, but many others follow the general family characteristics. Differences in ovigerous female size in the genus Austinixa can be related to environmental characteristics such as burrow size of the host and host size (Peiró et al. 2013). In general, differences in latitude affect environmental conditions (such as temperature and salinity) and availability of resources (such as food and shelter) (Mantelatto \& Garcia 1999, Mantelatto et al. 2002), and consequently, also act on the mesohabitat of the host. The combination of all these factors influences reproduction in symbiotic species, as discussed below.

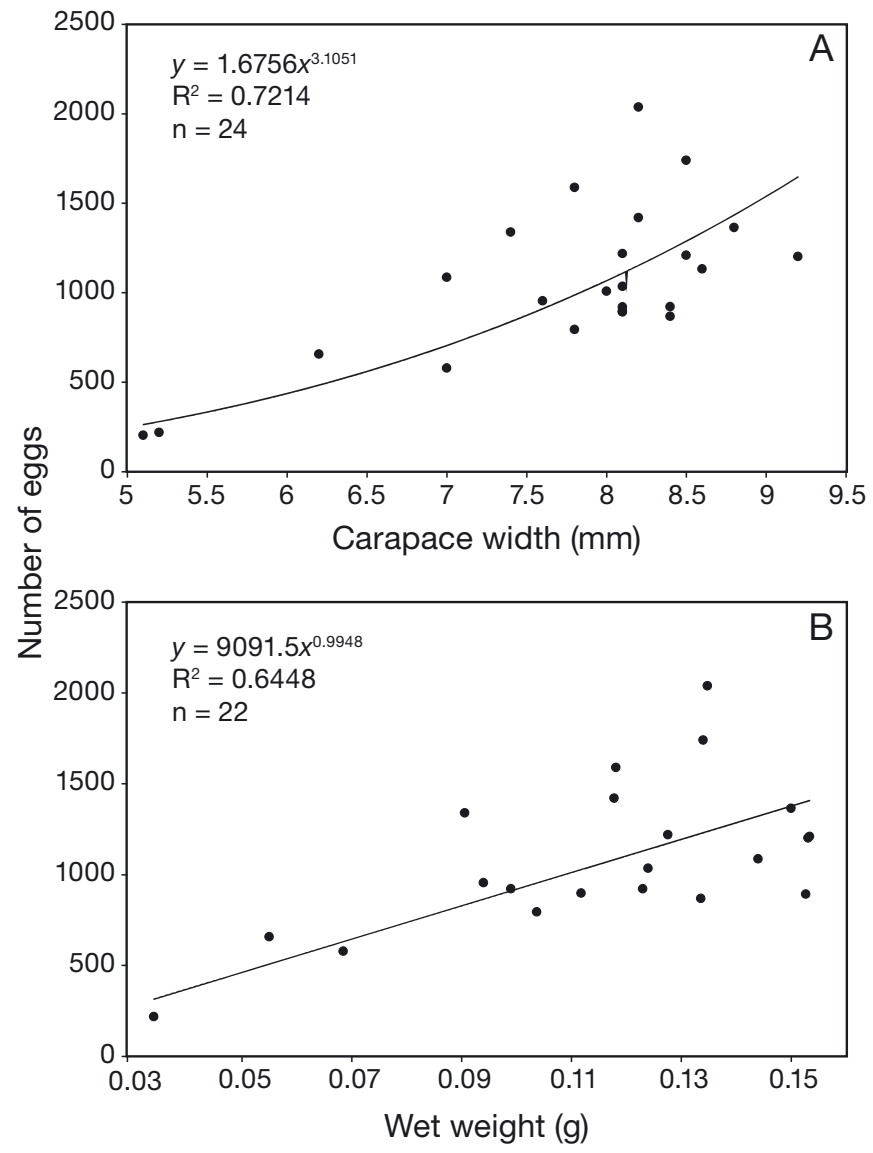

Fig. 5. Relationship between fecundity (number of eggs) and (A) carapace width and (B) wet weight of Austinixa aidae ovigerous females collected in Callichirus galleries at Perequê-açu beach, Ubatuba, São Paulo, Brazil, from May 2005 to September 2006

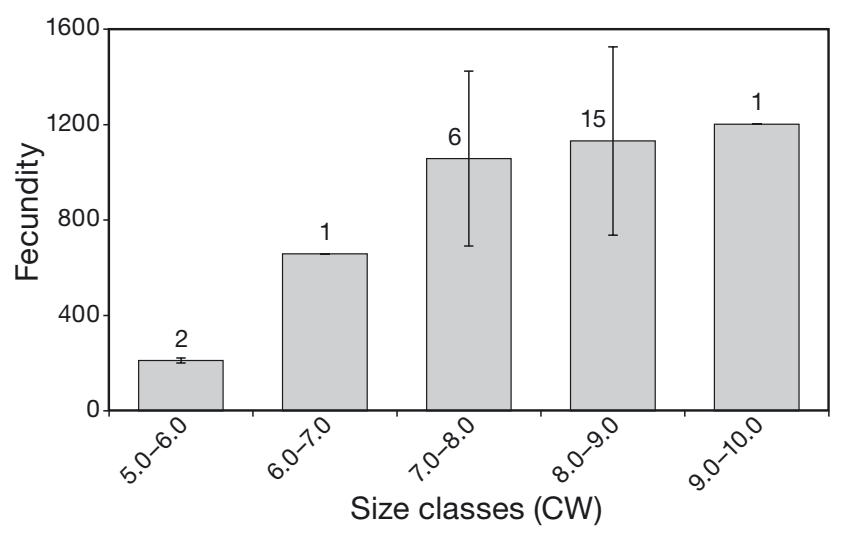

Fig. 6. Mean fecundity (number of eggs) by size class ( $\mathrm{CW}=$ carapace width in $\mathrm{mm}$ ) in Austinixa aidae ovigerous females collected at Perequê-açu beach, Ubatuba, São Paulo, Brazil, from May 2005 to September 2006. Lines represent standard deviations. The numbers above the bars indicate the total number of individuals per stage 

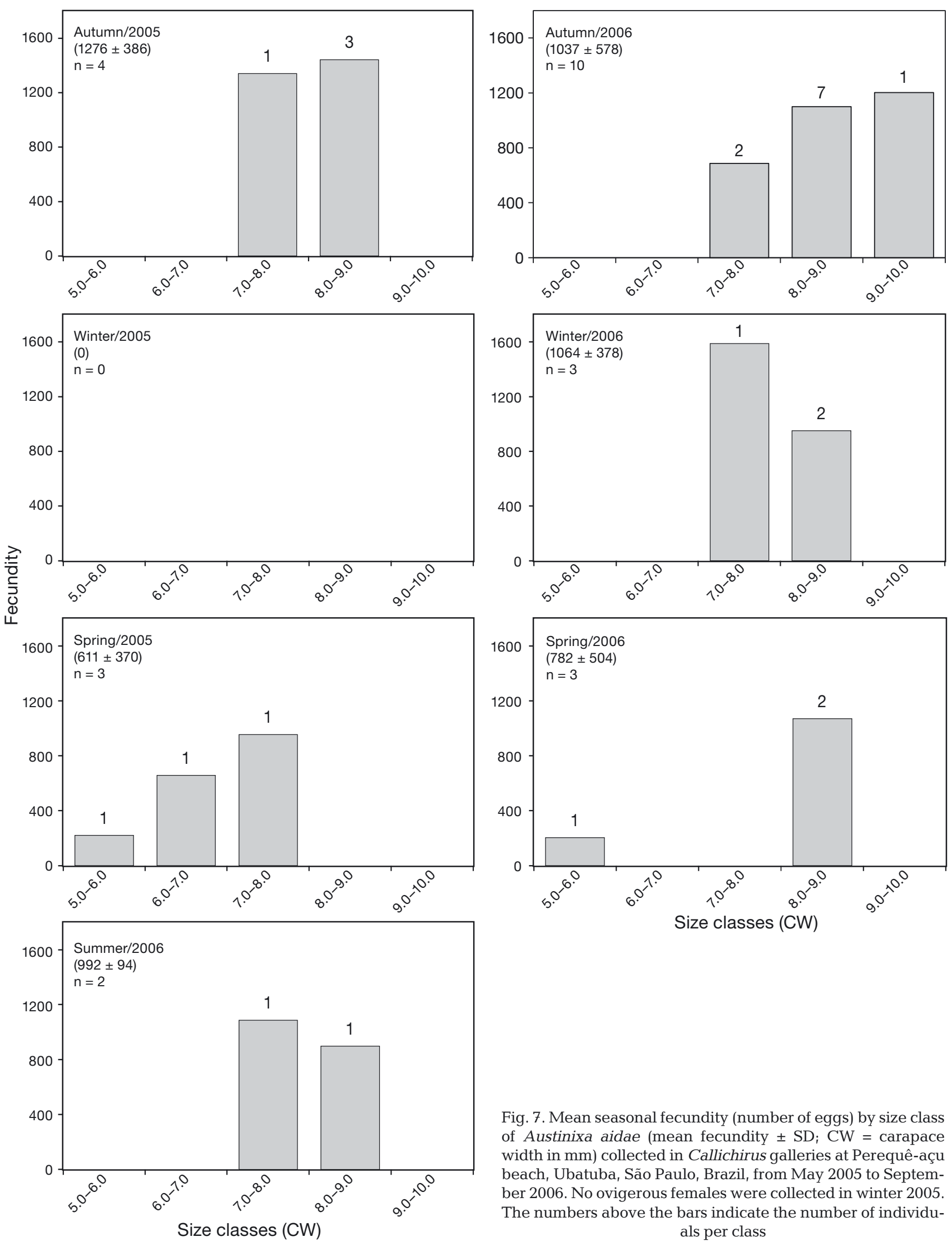

Fig. 7. Mean seasonal fecundity (number of eggs) by size class of Austinixa aidae (mean fecundity $\pm \mathrm{SD}$; $\mathrm{CW}=$ carapace width in $\mathrm{mm}$ ) collected in Callichirus galleries at Perequê-açu beach, Ubatuba, São Paulo, Brazil, from May 2005 to September 2006. No ovigerous females were collected in winter 2005. The numbers above the bars indicate the number of individuals per class 
The host body plan or host body size might influence differences in ovigerous female body size of the symbiotic species. The larger the host size, the larger the size and/or the number of symbiotic individuals. This rule has been observed in several parasitic species, including pinnotherid crabs (see Kane \& Farley 2006, pea crab Tumidotheres maculatus). The same pattern has also been observed with the symbiotic A. aidae (Peiró et al. 2013). Our results showed that ovigerous females of $A$. aidae have a broader size range than other species in the genus (from 5.1 to $10.5 \mathrm{~mm} \mathrm{CW}$ ). For instance, A. patagoniensis ranges in size from 8.0 to $11.2 \mathrm{~mm}$, a size that is associated with Sergio mirim (Rodrigues, 1971) (Alves \& Pezzuto 1998) and Callichirus sp. (Alves et al. 2005); A. gorei ranges in size from 6.3 to $8.3 \mathrm{~mm}$, a size that is associated with Gilvossius setimanus (DeKay, 1844) (McDermott 2006). Each pinnotherid host cited above is from the family Callianassidae. Probable differences in burrow structure, water availability promoted by the host (offering oxygenation and food), and geographical location (latitude) may influence the differences among the cited symbiotic pinnotherids.

Our results regarding the relationship between the AW/CW ratios and CW corroborate the previous allometric study by Peiró et al. (2011). Sexual maturity was reached at the size of the smallest ovigerous female (5.1 mm CW). According to Hartnoll (1982), an enlarged abdomen is evidence of sexual maturity. This feature is the most effective means of determining physiological and morphological maturation because the incubation and protection of eggs depends on this structure. In many cases, morphological maturity is also associated with gonadal maturity, allowing one to infer that morphologically mature individuals are also functionally mature (Pinheiro \& Terceiro 2000, Peiró et al. 2011).

Among decapods, reproductive traits have been observed to vary with temperature and salinity (Giese 1959, Pinheiro \& Fransozo 1995). Nevertheless, fecundity in $A$. aidae was not correlated with temperature and salinity (Peiró \& Mantelatto 2011); ovigerous females, which are more susceptible to these factors (Sastry 1983), were also not influenced by seasonality. We have 2 non-exclusive explanations for the lack of match between biological traits and the environmental parameters: (1) It may be caused by the methodology used to obtain the temperature parameter. This was made during the day of sampling, thus not offering a general overview of the periodic variation. (2) It may be due to the relative stability of abiotic (environmental) factors inside the burrow. However, these hypotheses must be tested in further studies.

The frequency of ovigerous females indicates a variably continuous reproduction with increases between November and May (Figs. 1 \& 4), a period associated with elevation of temperature and a photoperiod with longer daylight hours (Bauer 1989, Müller \& Carpes 1991, Pavanelli et al. 2008). The reproductive period was classified as seasonally continuous (according Pinheiro \& Terceiro 2000) and was similar to that found for $A$. patagoniensis from southern Brazil by Alves \& Pezzuto (1998) (Table 1); both species occur in a subtropical climate.

Early stage eggs were the most frequent in all reproductive periods, an indicator of high reproductive performance (Fig. 4). This suggests a continuous reproductive cycle with seasonal variation (season-

Table 1. Minimum size (carapace width) of ovigerous females, mean fecundity, reproductive period, and hosts of Austinixa species from sandy beaches in the southeastern USA and southern and southeastern Brazil. na: not available

\begin{tabular}{|c|c|c|c|c|c|c|}
\hline Species & $\begin{array}{l}\text { Locality } \\
\text { (Latitude) }\end{array}$ & $\begin{array}{l}\text { Min. size of } \\
\text { ovigerous } \\
\text { females }(\mathrm{mm})\end{array}$ & $\begin{array}{l}\text { Mean number } \\
\text { of eggs } \\
\text { (min.-max.) }\end{array}$ & $\begin{array}{c}\text { Callianassidae } \\
\text { host }\end{array}$ & $\begin{array}{l}\text { Reproductive } \\
\text { period }\end{array}$ & References \\
\hline Austinixa gorei & $\begin{array}{l}\text { Miami, USA } \\
\left(25^{\circ} 43^{\prime} \mathrm{N}\right)\end{array}$ & 6.3 & na (195-525) & $\begin{array}{l}\text { Gilvossius } \\
\text { setimanus }\end{array}$ & na & McDermott (2006) \\
\hline A. aidae & $\begin{array}{l}\text { Ubatuba, Brazil } \\
\left(23^{\circ} 24^{\prime} \mathrm{S}\right)\end{array}$ & 5.1 & $\begin{array}{c}1124 \\
(204-2039)\end{array}$ & Callichirus sp. & $\begin{array}{l}\text { Seasonal- } \\
\text { continuous }\end{array}$ & $\begin{array}{l}\text { Present study } \\
\text { Peiró \& Mantelatto (2011), } \\
\text { Peiró et al. (2011), } \\
\text { Peiró et al. (2013) }\end{array}$ \\
\hline A. patagoniensis & $\begin{array}{c}\text { Balneário } \\
\text { Camboriú, Brazil } \\
\left(26^{\circ} 59^{\prime} \mathrm{S}\right)\end{array}$ & 7.9 & $\begin{array}{c}1719 \\
(933-2747)\end{array}$ & Callichirus sp. & Continuous & Alves et al. (2005) \\
\hline A. patagoniensis & $\begin{array}{c}\text { Balneário } \\
\text { Cassino, Brazil } \\
\left(32^{\circ} 13^{\prime} \mathrm{S}\right)\end{array}$ & 8.0 & $\begin{array}{c}1529 \\
(830-2472)\end{array}$ & Sergio mirim & $\begin{array}{l}\text { Seasonal } \\
\text { (October to } \\
\text { March) }\end{array}$ & Alves \& Pezzuto (1998) \\
\hline
\end{tabular}


ally continuous reproduction) and rapid embryonic development. The proportion of the different egg stages found during our study period indicated quick embryonic development, although we did not determine a precise time of incubation based on our observations. Further investigations are recommended to obtain this information.

Fecundity in $A$. aidae is intermediate when compared to A. patagoniensis and A. gorei (Table 1). Egg production is strongly correlated with female body dimension (size), and the number of eggs tends to increase as the width and/or length of the carapace increases, a relationship commonly observed in diverse groups of decapods (Hines 1988, Corey \& Reid 1991, Anger \& Moreira 1998, Mantelatto et al. 2002). Despite some exceptions, in most decapods, fecundity and the most representative body size dimension (carapace width and/or weight) are positively correlated (Sastry 1983). This correlation has been observed in A. aidae (present study), A. patagoniensis (Alves \& Pezzuto 1998) and A. gorei (McDermott 2006), indicating that the pea crabs of the genus Austinixa also follow the decapod pattern, as in many symbiotic pinnotherid crabs (Hines 1992).

An important factor that affects fecundity is the primiparous or multiparous spawning condition of females. Little variation in egg number was observed within individual size classes. Considering body size, the lowest fecundities were observed in females who most likely were spawning for the first time. Primiparous females produce fewer eggs than multiparous females, but they still contribute to an increase in population size (Somerton \& Meyers 1983, Mantelatto \& Garcia 1999). According to Somerton \& Meyers (1983), primiparous female Alaskan tanner crabs Chionoecetes bairdi allocate most of their energy to growth, consequently reducing the amount of energy used for egg production, whereas multiparous females divert most of their energy toward egg production. The same pattern was found in this study, with a species living in very different environmental conditions.

Environmental conditions must also be considered in fecundity analysis because variation in fecundity is observed even within the same genus (Mantelatto \& Garcia 1999), as reported here (Table 1). These intraspecific variations are related to environmental adaptations, variations in body size and geographic location (Mantelatto \& Fransozo 1997), and latitudinal variations (Lardies \& Wehrtmann 2011), with greater egg production in higher latitude than in lower latitude populations/species (Jones \& Simons 1983). Egg size of A. aidae is similar to that of A. gorei from Miami, USA, a similar latitude in a different hemisphere (McDermott 2006). Studies with more species are recommended to determine the relationship between fecundity and latitude. However, differences in egg size may partly be attributed to differences in reproductive strategies (Mantelatto \& Garcia 1999). Most likely, the reproductive performance in $A$. aidae is related to the size of the host and the polygynandrous mating system of $A$. aidae, where males move between burrows in search of receptive females (Peiró et al. 2013).

The behavior, maturity, fecundity, breading season, spawning, and egg hatching in Decapoda result from the coordinated action of endogenous and exogenous factors (Sastry 1983, Pinheiro \& Terceiro 2000), and the host may influence these reproductive parameters (i.e. host size, Peiró et al. 2013). In A. aidae, reproductive aspects may be related to the mean size of the species. In fact, we have shown a dependence (limitation) of the 'guest' (Pinnotheridae) host burrow size (protection and refuge for growth and reproduction), which itself depends on the size of the host. These crabs are among the smallest symbiotic Brachyura, and the body size of the host shelter has a positive relationship with fecundity (Peiró et al. 2013).

Other parameters must be studied to understand the reproductive complexity of this symbiotic species. For instance, the existence of larval migration/ settlement is a key factor determining whether larvae settle in the same place where they live as mature individuals (like some pinnotherid species). When compared with other species of the genus, $A$. aidae has similar ecological and biological patterns with some unique features related to the region where they are found and to the host-use pattern (see Peiró et al. 2013 for review). The next step to study the effect of larval migration/settlement on the $A$. aidae life cycle may involve experimental studies to observe Pinnotheridae behavior with their hosts.

Acknowledgements. This study was supported by a fellowship from CAPES-Brazil (Coordenação de Aperfeiçoamento de Pessoal de Nível Superior) awarded to D.F.P. F.L.M. and D.F.P. are grateful to CNPq-Brazil (Conselho Nacional de Desenvolvimento Cientifico e Tecnológico) for research (302748/2010-5) and PhD (GD 141446/2009-9 and SWE 201831/2010-4) grants, respectively. Part of this study was supported by funding from a CNPq grant (471794/2006-6; 473050/2007-2; 302748/2010-5), FAPESP-Brazil (Fundação de Amparo à Pesquisa do Estado de São Paulo, 2010/501888) and CAPES (Ciências do Mar II Proc. 2005/201423038.004308/201414) to F.L.M. D.F.P. is supported by an ongoing postdoctoral fellowship from CAPES/COFECUB. Special thanks to all members of the Bioecology and Crustacean Systematics Laboratory of FFCLRP/USP for their help 
during field and laboratory work and also to Paulo R. Pezzuto for his suggestions. The support of the Postgraduate Program in Comparative Biology of the FFCLRP/USP and the Centro de Biologia Marinha da Universidade de São Paulo (CEBIMar/USP) during sample collection is also acknowledged. We thank American Journal Experts for revising the English text. We are very thankful to Dr. Raymond Bauer and to anonymous reviewers for they comments and suggestions during the revision process. All experiments in this study complied with current state and federal laws of Brazil.

\section{LITERATURE CITED}

Alves ES, Pezzuto PR (1998) Population dynamics of Pinnixa patagoniensis Rathbun, 1918 (Brachyura: Pinnotheridae) a symbiotic crab of Sergio mirim (Thalassinidea: Callianassidae) in Cassino Beach, Southern Brazil. Mar Ecol (Berl) 19:37-51

Alves ES, Rodrigues SA, Pezzuto PR (2005) Estudo do crescimento relativo de Austinixa patagoniensis (Rathbun) (Decapoda, Pinnotheridae) simbionte de Callichirus major (Say) (Decapoda, Callianassidae) no mesolitoral da praia de Balneário Camboriú, Santa Catarina, Brasil. Rev Bras Zool 22:784-792

Anger K, Moreira GS (1998) Morphometric and reproductive traits of tropical caridean shrimps. J Crustac Biol 18: 823-838

Bauer RT (1989) Continuous reproduction and episodic recruitment in nine shrimp species inhabiting a tropical seagrass meadow. J Exp Mar Biol Ecol 127:175-187

Bauer RT (2004) Remarkable shrimps: adaptations and natural history of the Carideans. University of Oklahoma Press, Norman, OK

Bell JL, Stancyk SE (1983) Population dynamics and reproduction of Dissodactylus mellitae (Brachyura: Pinnotheridae) on its sand dollar host Mellita quinquiesperforata (Echinodermata). J Exp Mar Biol Ecol 13:141-149

Boolootian RA, Giese AC, Farmanfarmain A, Tucker J (1959) Reproductive cycles of five West Coast crabs. Physiol Zool 32:213-220

> Corey S, Reid DM (1991) Comparative fecundity of decapod crustaceans. I. The fecundity of thirty-three species of nine families of caridean shrimp. Crustaceana 60:270-294

> Giese AC (1959) Comparative physiology: annual reproductive cycles of marine invertebrates. Annu Rev Physiol 21: 547-576

Harrison JS (2004) Evolution, biogeography, and the utility of mitochondrial $16 \mathrm{~S}$ and COI genes in phylogenetic analysis of the grab genus Austinixa (Decapoda: Pinnotheridae). Mol Phylogenet Evol 30:743-754

- Harrison JS, Hanley PW (2005) Austinixa aidae Righi, 1967 and A. hardyi Heard and Manning, 1997 (Decapoda: Brachyura: Pinnotheridae) synonymized, with comments on molecular and morphometric methods in crustacean taxonomy. J Nat Hist 39:3649-3662

Hartnoll RG (1982) Growth. In: Bliss DE (ed) The biology of Crustacea, embryology, morphology, and genetics. Academic Press, New York, NY, p 11-196

Hartnoll RG, Gould P (1988) Brachyuran life history strategies and the optimization of egg production. In: Finchan AA, Rainbow PS (eds) Aspects of decapod crustacean biology. Clarendon Press, Oxford, p 1-9

Heard RW, Manning RB (1997) Austinixa, a new genus of pinnotherid crab (Crustacea: Decapoda: Brachyura), with the description of $A$. hardyi, a new species from Tobago, West Indies. Proc Biol Soc Wash 110:393-398

Hernáez P, Palma S (2003) Fecundidad, volumen del huevo y rendimiento reproductivo de cinco especies de porcelánidos intermareales del norte de Chile (Decapoda, Porcellanidae). Invest Mar 31:35-46

Hines AH (1988) Fecundity and reproductive output in two species of deep-sea crabs, Geryon fenneri and G. quinquedens (Decapoda: Brachyura). J Crustac Biol 8: $557-562$

Hines AH (1992) Constraint on reproductive output in brachyuran crabs: Pinnotherids test the rule. Am Zool 32: 503-511

Jones MB, Simons MJ (1983) Latitudinal variation in reproductive characteristics of a mud crab, Helicecrassa (Grapsidae). Bull Mar Sci 33:656-670

Kane K, Farley GS (2006) Body size of the endosymbiotic pea crab Tumidotheres maculatus: Larger hosts hold larger crabs. Gulf Caribb Res 18:27-33

Lardies MA, Castilla JC (2001) Latitudinal variation in the reproductive biology of the commensal crab Pinnaxodes chilensis (Decapoda: Pinnotheridae) along the Chilean coast. Mar Biol 139:1125-1133

Lardies MA, Wehrtmann IS (1996) Aspects of the reproductive biology of Petrolisthes laevigatus (Guérin, 1835) (Decapoda, Anomura, Porcellanidae). I. Reproductive output and chemical composition of eggs during embryonic development. Arch Fish Mar Res 43:121-135

Lardies MA, Wehrtmann IS (2011) Gonadal development in males of Notocrangon antarcticus (Decapoda: Caridea) from the Weddell Sea, Antarctica. Polar Biol 34:707-713

> Manning RB (1975) Two methods for collecting decapods in shallow water. Crustaceana 29:317-319

> Mantelatto FL, Fransozo A (1997) Fecundity of the crab Callinictes ornatus Ordway, 1863 (Decapoda, Brachyura, Portunidae) from the Ubatuba region, São Paulo, Brazil. Crustaceana 70:214-226

> Mantelatto FL, Garcia RB (1999) Reproductive potential of the hermit crab Calcinus tibicen (Anomura) from Ubatuba, São Paulo, Brazil. J Crustac Biol 19:268-275

> Mantelatto FL, Alarcon VF, Garcia RB (2002) Egg production strategies of the tropical hermit crab Paguristes tortugae from Brazil. J Crustac Biol 22:390-397

> McDermott JJ (2005) Biology of the brachyuran crab Pinnixa chaetopterana Stimpson (Decapoda: Pinnotheridae) symbiotic with tubicolous polychaetes along the Atlantic coast of the United States, with additional notes on other polychaete associations. Proc Biol Soc Wash 118:742-764

McDermott JJ (2006) The biology of Austinixa gorei (Manning \& Felder, 1989) (Decapoda, Brachyura, Pinnotheridae) symbiotic in the burrows of intertidal ghost shrimp (Decapoda, Thalassinidea, Callianassidae) in Miami, Florida. Crustaceana 79:345-361

Müller YMR, Carpes S (1991) Macrobrachium potiuna (Müller): aspectos do ciclo reprodutivo e sua relação com parâmetros ambientais (Crustacea, Decapoda, Palaemonidae). Rev Bras Zool 8:23-30

> Ocampo EH, Nuñez JD, Cledón M, Baeza JA (2012) Hostspecific reproductive benefits, host selection behavior and host use pattern of the pinnotherid crab Calyptraeotheres garthi. J Exp Mar Biol Ecol 429:36-46

Ogawa EF, Rocha CAS (1976) Sobre a fecundidade de crustáceos decápodos marinhos no Estado do Ceará, Brasil. Arq Ciênc Mar 16:101-104 
Pavanelli CAM, Mossolin EC, Mantelatto FL (2008) Reproductive strategy of the snapping shrimp Alpheus armillatus H. Milne Edwards, 1837 in the South Atlantic: fecundity, egg features, and reproductive output. Invertebr Reprod Develop 52:123-130

Peiró DF, Mantelatto FL (2011) Population dynamics of the pea crab Austinixa aidae (Brachyura, Pinnotheridae): a symbiotic of the ghost shrimp Callichirus major (Thalassinidea, Callianassidae) from the southwestern Atlantic. Iheringia Sér Zool 101:5-14

Peiró DF, Pezzuto PR, Mantelatto FL (2011) Relative growth and sexual dimorphism of Austinixa aidae (Brachyura: Pinnotheridae): a symbiont of the ghost shrimp Callichirus major from the southwestern Atlantic. Lat Am J Aquat Res 39:261-270

Peiró DF, Baeza JA, Mantelatto FL (2013) Host-use pattern and sexual dimorphism reveals the mating system of the symbiotic pea crab Austinixa aidae (Crustacea: Brachyura: Pinnotheridae). J Mar Biol Assoc UK 93:715-723

Pinheiro MAA, Fransozo A (1995) Fecundidade de Pachycheles haigae Rodrigues da Costa, 1960 (Crustacea, Anomura, Porcellanidae) em Ubatuba (SP), Brasil. Rev Bras Biol 55:623-631

Pinheiro MAA, Terceiro OSL (2000) Fecundity and reproductive output of the speckled swimming crab Arenaeus cribrarius (Lamarck, 1818) (Brachyura, Portunidae). Crustaceana 73:1121-1137

Editorial responsibility: Raymond Bauer,

Lafayette, Louisiana, USA
Rodrigues SA (1966) Estudos sobre Callianassa: Sistemática, Biologia e Anatomia. PhD dissertation, University of São Paulo

Sastry AN (1983) Ecological aspects of reproduction. In: Vernberg FJ, Vernberg WB (eds) The biology of Crustacea VIII. Environmental adaptations. Academic Press, New York, NY, p 179-270

Schmitt WL, Mccain JC, Davidson ES (1973) Decapoda I. Brachyura I. Family Pinnotheridae. In: Gruner HE, Holthuis LB (eds) Crustaceorum catalogus, Vol 3. W. Junk, The Hague, p 32-37

Somerton DA, Meyers WS (1983) Fecundity differences between primiparous and multiparous female Alaskan tanner crab (Chionoecetes bairdi). J Crustac Biol 3: 183-186

Sturges HA (1926) The choice of a class interval. J Am Stat Assoc 21:65-66

Timofeev SF, Sklyar VV (2001) Egg size in the Euphasiid, Thysanoes saraschii (M. Sars, 1864) (Euphausiacea) in the Barents Sea. Crustaceana 74:1201-1211

Turra A, Leite FPP (2000) Population biology and growth of three sympatric species of intertidal hermit crab in southeastern Brazil. J Mar Biol Assoc UK 80:1061-1069

Williams AB (1984) Shrimps, lobsters and crabs of the Atlantic coast of the eastern United States, Maine to Florida. Smithsonian Institution, Washington, DC

Zar JH (1996) Biostatistical analysis. Prentice-Hall, Upper Saddle River, NJ

Submitted: March 31, 2014; Accepted: October 6, 2014 Proofs received from author(s): November 21, 2014 